\title{
Male Features in the Political Discourse of Female Politicians
}

\author{
Ruzanna Arustamyan \\ Yerevan State University
}

\begin{abstract}
The article is devoted to the description of masculine manner of speech in the discourse of female politicians. Being mainly a field of male activity, politics has become the area of strict rules, perseverance, pertinacity and leadership. The main point in politics is struggle and tough competition of interests. In these conditions strict power qualities exacerbate, humanism disappears in actions and behaviour. This exact style is typical of men, and not women, hence if a woman goes into politics, she has to play according to male rules achieving tough and uncompromising manners of speech. Therefore, entering this complex sphere, women need to obtain analytical, logical, direct and unemotional way of thinking both for their activity and speech. These are necessary qualities for being a successful politician and a person, who will obtain fame, respect and love of citizens. The materials chosen for the analysis are the speeches of two famous women politicians of different periods: Margaret Thatcher and Condoleezza Rice. The main method of linguistic analysis is comparison, i.e. we choose certain parts from speeches of both politicians and try to find male characteristic features.
\end{abstract}

Key words: political discourse, male and female speech, gender communication, language and gender, gender difference.

\section{Introduction}

Language is both personal and social. On the one hand, we can use language to express our internal thoughts and desires. On the other hand, language exists outside of us, because society influences and dictates the needs and demands of the use of certain terms, which are changeable in different periods of history.

Language reflects society. It reflects gender division. The linguistic patterns people adopt are influenced much by the interaction patterns, by the people one regularly talks to and by the social status of the people who are concerned. Language is sensitive to the living patterns and the interaction patterns. "In these ways one can say certain sex differences in language behavior are a side effect of the systematically different social experiences of women and men" (Graddol, Swann 1989:9). Language is a means of communication. Communication takes a large part in the process in which we become male or female because males and females are taught different linguistic practices. For example, females are often more expressive and intuitive in their communication, while 
males tend to be instrumental and competitive. In addition, there are differences in accepted communication behaviors for males and females. To improve communication between genders, one must understand these differences found in the opposite sex.

\section{The Analysis of Political Discourse of Female Politicians}

\section{(on the example of Margaret Thatcher and Condoleezza Rice)}

The communicative behaviour of men and women has always been sustainable during the development of mankind. Traditionally the role of men was active, whereas women's role was considered only as careful mother and wife. The stereotype of "housewife" was dominant in the society and was conditioned by the performance of "natural" publicly accepted duties (Platoshina, Novikova 2012:232).

Throughout history, the public image of a female politician has been influenced by the notion that the identity of a 'politician' is male.

Nowadays the situation has somewhat changed. From the second half of the $20^{\text {th }}$ century women tend to change this stereotype and are actively involved in many spheres, particularly in politics. Despite the performance of "natural" role of mother and wife, women seek to participate in decision-making processes, obtaining masculine features of behaviour both in actions and speech.

The article aims to reveal masculine features in the speeches of two outstanding female political leaders: Margaret Thatcher and Condoleezza Rice. Although they were in office in different periods of time, we will try to find similar features, which distinguish them from other women politicians.

Margaret Hilda Thatcher, Baroness Thatcher was the from 1979 to 1990 and the from 1975 to 1990. She was the longest-serving British Prime Minister of the 20th century and is the only woman to have held the office. A journalist Yuri Gavrilov called her the "Iron Lady", a nickname that became associated with her uncompromising politics and leadership style. As Prime Minister, she implemented policies that have come to be known as Thatcherism. (<http://en.wikipedia.org/wiki/Margaret_Thatcher\#cite_note-ironlady-68>).

Many examples of Thatcher's discourse prove her confident, ambitious, uncompromising and direct nature. Such style is not typical of women. This is the reason why it attracts the attention to the peculiar communicative behaviour of "the Iron Lady". We will try to observe these features in the following examples:

If you set out to be liked, you would be prepared to compromise on anything at any time, and you would achieve nothing.

(<http://www.brainyquote.com/quotes/authors/m/margaret_thatcher.html\#

$$
\text { QFbPWcsqZgzXxY4j.99>) }
$$


Here she uses to compromise to show that she is not going to compromise to be liked. Here we see an example how a person should behave according to the so-called rules of gender behaviour when women have to become incompliant. In politics one has no right to compromise, especially women.

My statement yesterday explained the Government's decision to support the United States military action, taken in self-defence, against terrorist targets in Libya...

...In April 1984 we took our own measures. We closed the Libyan people's bureau in London and broke diplomatic relations with Libya. We imposed a strict visa regime on Libyans coming to this country and we banned new contracts for the supply of defence equipment and we severely limited Export Credits Guarantee Department credit for other trade...

(<http://www.margaretthatcher.org/speeches/displaydocument.asp $\times$ docid $=106363>$ )

We can notice that Mrs. Thatcher praises the anti-terrorism cooperation only by using military attacks. Such verbs as close, impose, break, ban, limit reveal tough and uncompromising stance of the prime-minister. The use of "strict" verbs is typical of male politicians. Usually female politicians do not seek to resolve problems via military intervention. We may follow such example in the discourse of Hillary Clinton on issue of Iran nuclear weapon.

I am against a rush to war. I was the first person on this stage and one of the very first in the Congress to go to the floor of the Senate back in February and say Bush had no authority to take any military action in Iran. Secondly, I am not in favor of this rush for war, but I'm also not in favor of doing nothing. Iran is seeking nuclear weapons. And the Iranian Revolutionary Guard is in the forefront of that, as they are in the sponsorship of terrorism. So some may want a false choice between rushing to war, which is the way the Republicans sound - it's not even a question of whether, it's a question of when and what weapons to useand doing nothing. I prefer vigorous diplomacy. And I happen to think economic sanctions are part of vigorous diplomacy. We used them with respect to North Korea. We used them with respect to Libya.

(<http://www.nytimes.com/2007/10/30/us/politics/30debatetranscript.htm

$1 \times$ pagewanted $=$ print\&_r $=0>$ ) 
These anti-war expressions against a rush to war, not in favour of this rush war show that Clinton seeks to resolve conflicts via peaceful settlement. The expression vigorous diplomacy exemplifies the eagerness to find a resolution through active diplomatic channels. Whereas, Mrs. Thatcher is not used to resolving problems through winning concessions. She used to be stubborn and strong-willed, and that is the secret of her success. In one of her speeches Thatcher says, "I am not a consensus politician. I'm a conviction politician." This expression is the apogee of self-confident character of the politician. This kind of statement may be seen as not only the declaration of selfconfidence and strong uncompromising nature, but also as a tool to preserve the stance of a woman in a manmade world, when a woman has no choice but being severe in the political arena.

Margaret Thatcher's career is a vivid example how a woman acquiring male characteristic features became one of the most influential and strong female political leaders throughout the whole history of politics.

The following statement was mentioned in one of the articles of Rossiyskaya Gazeta (Zakharchuk 2012:22):

Thatcher didn't adjust herself to the Conservative Party...She adjusted the party to herself and embodied the party in herself. And when the time came and the power was concentrated in her hands, she began to change the party.

Thus, the unshaken rhetoric of Thatcher gained her the nickname the "Iron Lady", which explains much of the firmness of her speeches addressed to the public. Such words as didn't adjust herself; change the party; concentrate power reveal the uncompromising, stable and powerful nature of the prime-minister, which again is not peculiar to women.

When we look through the speech delivered at Kensington Town Hall in January 19, 1976 it is seen that through anaphors the politician shows her readiness to carry out the activities against a superpower, i.e. trying to cease a Soviet Union military force expansion. Here we see how a woman politician is aware of all military staff. Confident use of the pronoun "I" expresses the motivated and self-confident position of the primeminister. The pronoun "I" is inherent to male politicians, because of their competitive nature, whereas women tend to use the pronoun "we" to show their compassionate and collaborative nature. Thatcher is readily concentrating all the actions around herself, representing the concept of strong willingness to change the direction of Soviet Union's strategy.

Some military experts believe that Russia has already achieved strategic superiority over America. 
But it is the balance of conventional forces which poses the most immediate dangers for NATO.

I am going to visit our troops in Germany on Thursday. I am going at a moment when the Warsaw Pact forces - that is, the forces of Russia and her allies - in Central Europe outnumber NATOs by 150,000 men nearly 10,000 tanks and 2,600 aircraft.

I would be the first to welcome any evidence that the Russians are ready to enter into a genuine detente. But I am afraid that the evidence points the other way.

I warned before Helsinki of the dangers of falling for an illusory détente.

(<http://www.margaretthatcher.org/document/102939>)

"Let me give you my vision" is the speech delivered on 10 October 1975, where Thatcher represents a new direction, which will lead the country further. In the following examples we see the superiority of capitalism over communism.

Whenever I visit Communist countries their politicians never hesitate to boast about their achievements. They know them all by heart; they reel off the facts and figures, claiming this is the rich harvest of the Communist system. Yet they are not free as we in the West are prosperous, and they are not free as we in the West are free.

Our capitalist system produces a far higher standard of prosperity and happiness because it believes in incentive and opportunity, and because it is founded on human dignity and freedom. Even the Russians have to go to a capitalist country - America - to buy enough wheat to feed their people - and that after more than fifty years of a Statecontrolled economy. Yet they boast incessantly, while we, who have so much more to boast about, forever criticize and decry. Is it not time we spoke up for our way of life $\times$

On this example we observe the negative attitude of Thatcher towards the communist system. She is using verbs with negative connotations. The use of the words - to boast - to talk with excessive pride, to reel off - to crack, - imparts additional significance to the words. The phrase to know by heart in this context bears evaluative overtone, because it does not reflect the real state of affairs, it sounds sarcastic. Then we come up to the rhetorical question: Is it not time we spoke up for our way of life $\times$, which serves as a vivid and expressive form for the evidence of the basic idea. 
In general, the discourse of female politicians is characterized by the abundance of evaluative epithets, which convey emotional tone to the speech. We can observe this phenomenon on the examples of Hillary Clinton and Madlen Albright's discourse:

Madeleine Albright:

We have had very good discussions.

(<http://fas.org/news/ukraine/98030903_wpo.html >)

I am happy to report that a truly impressive coalition of leading companies has supported this process and welcomed these principles. (<http://1997-2001.state.gov/www/statements/2000/001220.html>)

The second item of news is that I am pleased to announce the successful culmination of an unprecedented dialogue initiated by the State Department and the British Foreign Office.

(<http://1997-2001.state.gov/www/statements/2000/001220.html>)

Besides emotive adjectives, the use of hedges is widely spread among women. We may observe them in the speeches of Hillary Clinton:

So I can imagine who only, you know, follow it from, you know, some of the snippets on TV might, you know not be sure exactly who's saying what and what the campaigns are doing.

( $<$ http://edition.cnn.com/TRANSCRIPTS/0804/21/lk1.01.html $>)$

Many linguists state that the use of hedges is conditioned by the willingness to express solidarity and not to hurt the interlocutor. Therefore, the hedge you know is used for the involvement of the interlocutor in the conversation. It is also worth mentioning that the hedge may be used as an indicator of the lack of conviction and as a signal for displaying support.

R. Lakoff entitles the above mentioned characteristic features as "ladylike talk", i.e. the expressions and sentence constructions inherent to women (Lakoff 1975:321).

Contrary to these "ladylike" peculiarities we can observe another example of "manlike" discourse on the example of Condoleezza Rice. Condoleezza "Condi" Rice is an American political scientist and diplomat. She served as the $66^{\text {th }}$ United States Secretary of State, and was the second person to hold that office in the administration of President George W. Bush. (<http://en.wikipedia.org/wiki/Condoleezza_Rice>)

Many political scientists consider Condoleezza Rice to be the follower of "Iron Lady". We will try to make a little overview and to decide whether these similarities do exist or not. 
The U.N. charter certainly endorses self-defense. And the U.N. charter - it is under the U.N. charter that the resolutions were put together that are supposed to constrain Saddam Hussein and to disarm him so that he is not a threat to peace and security...

...We're in a new world. We're in a world in which the possibility of terrorism, married up with technology, could make us very, very sorry that we didn't act.

...It makes ever more urgent the continued war against al Qaeda, the continued support for our allies, who are helping us to fight that war. And it makes more urgent looking at other threats, like those who are building weapons of mass destruction and mean us ill...

(<http://edition.cnn.com/TRANSCRIPTS/0209/08/le.00.html >)

To disarm, to constrain, didn't act, fight that war, look at other threats shows the willingness of Ms. Rice to act and the readiness to resort to all sorts of methods to reach her aims, hence she views the struggle and war as the only way to solve the problems against dictatorship and terrorism. This way of thinking is not typical of women, because generally they tend to solve disputes in a peaceful manner without showing off their power.

With her steely nerve and delicate manners (she has been called the "Warrior Princess"), Rice lately has reinvigorated her position with diplomatic activism, whether it's promoting Israel's withdrawal from the Gaza Strip to ease the Palestinian conflict, or encouraging six-party talks to get North Korea to stop its pursuit of nuclear weapons, or trying to stop Sudan's genocide - to the point where her diplomatic party was recently roughed up by Sudan's strongmen.

(<http://www.forbes.com/lists/2005/11/MTNG.html $>$ )

In her speech in South Barrington Rice said:

...the defining characteristic of a true leader is that he or she never accepts the world as it is, but strives always to make the world as it should be.

\section{$(<$ http://www.brightquotes.com/lea_fr.html $>$ )}

The expressions never accepts, to make the world confirm her uncompromising character of a strong leader. She states that successful leader should not admit the reality as it is, but must seek to change it for the better.

When speaking against the Obama administration, Rice called for greater dedication in US leadership, saying: 
I fully understand the sense of weariness. I fully understand that we must think: 'Us, again $\times$ ' I know that we've been through two wars. I know that we've been vigilant against terrorism. I know that it's hard. But leaders can't afford to get tired. Leaders can't afford to be weary.

$(<\mathrm{http}: / /$ www.weeklystandard.com/blogs/condi-rice-blasts-obamaweakness-leadership_786123.html $>$ )

Again we see the repetition of the pronoun " $P$ ", which indicates a sign of self-focus and which shows exactly her own attitude towards different events.

The word-combinations can't afford to get tired, can't afford to be weary denote the intolerant nature of her character. She is ready to condemn every single administration and president if they do not correspond to her image of a dedicated leader.

I love policy, I do not really love politics.

(<http://www.nbcchicago.com/news/politics/Condoleeza-Rice-Will-Not-Be-MittRomneys-Vice-President-151947795.html >)

This means that she likes to conduct policy, to arrange everything in their certain places, to be a dedicated politician, who serves for ideas and principles but not showing. She is a woman that strives to work and to act.

Condoleezza Rice has been named one of the most powerful women in the world by the Forbes magazine. (<http://leadership.expert/leadership/great-leaders-condoleezzarice/>)

\section{Conclusion}

Tough and strict manner of the speech and the style of both female politicians is vividly expressed during their years in office. A perfected political image was Margaret Thatcher's answers to the problem of being a woman in a man's world. As far as political leadership was concerned, Thatcher did not wish to distinguish herself from men. She was tough in parliamentary and government affairs. Both political leaders express in their discourse the readiness to struggle against any kind of threat towards their country. As Prime Minister Thatcher could not conceal her private and family life but she endeavoured to make it look as perfect as possible. As for Ms. Rice, her style was very similar to the British prime-minister's tough style. Her confidence in her manner of speech and skills to get the job done and her professionalism to admit mistakes is clearly seen when she issues harsh statements during interviews. The main outcome of our research is that both female politicians tend to perform their style of discourse as strict, formal, discreet and perfect. They have similar strong character and 
will, which is necessary to resist pressure coming from male politicians, because being a female politician is a challenge, which demands hard work and uncompromising nature.

\section{References:}

1. Graddol, D. and Swann, J. (1989) Gender Voices. Cambridge: Blackwell.

2. Jandt, F.E. (2004) Gender Differences in Communication. Intercultural Communication: A Global Reader. Thousand Oaks, CA: Sage Publications.

3. Lakoff, R. (1975) Language and Women's Place. New York: Harper and Row.

4. Platoshina, V.V.; Novikova, A.I. (2012) Raspredeleniye rolei v rechevom povedenii muzhchin u jenshchin. Belgorod: NIU BelGU.

5. Zakharchuk, Y. (2012) Imidj meiking lidera: genderniy aspect. M.: Ideya.

\section{Sources of Data:}

1. Condoleezza Rice. Available at: <http://en.wikipedia.org/wiki/Condoleezza_Rice> [Accessed April 2015].

2. Condi Puts Romney Veep Rumors to Rest. Available at: <http:// www.nbcchicago.com/news/politics/Condoleeza-Rice-Will-Not-Be-Mitt-RomneysVice-President-151947795.html $>$ [Accessed May 2015].

3. Condi Rice Blasts Obama on Weakness, Leadership. Available at: $<$ http://www.weeklystandard.com/blogs/condi-rice-blasts-obama-weakness leadership_786123.html> [Accessed May 2015].

4. Interview with Senator Hillary Clinton. Available at: $<$ http://edition.cnn.com/TRANSCRIPTS/0804/21/lkl.01.html> [Accessed November 2015].

5. Interview with Condoleezza Rice; Pataki Talks About 9-11; Graham, Shelby Discuss War on Terrorism. Available at: <http://edition.cnn.com/TRANSCRIPTS/0209/08/le.00.html> [Accessed November 2015].

6. Interview with Condoleezza Rice; Pataki Talks About 9-11; Graham, Shelby Discuss War on Terrorism. Available at: <http://edition.cnn.com/TRANSCRIPTS/0209/08/le.00.html> [Accessed April 2015].

7. Leadership. Available at: <http://www.brightquotes.com/lea_fr.html > [Accessed May 2015].

8. Margaret Thatcher. Available at: $<$ http://en.wikipedia.org/wiki/Margaret_Thatcher\#cite_note-ironlady-68> [Accessed April 2015].

9. Margaret Thatcher. HCS: US Bombing of Libya. Available at: <http://www.margaretthatcher.org/speeches/displaydocument.asp $\times$ docid=106363 $>$ [Accessed April 2015]. 
10. Remarks of Albright and Udovenko in Kiev. Available at: $<$ http://fas.org/news/ukraine/98030903_wpo.html> [Accessed November 2015].

11. Secretary of State Madeleine K. Albright. Press Briefing. Available at: <http://19972001.state.gov/www/statements/2000/001220.html $>$ [Accessed November 2015].

12. The 100 Most Powerful Women. Available at: <http://www.forbes.com/lists/2005/11/MTNG.html> [Accessed in May 2015].

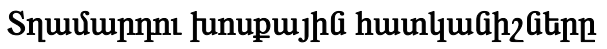

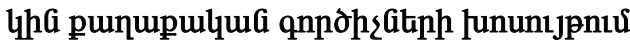

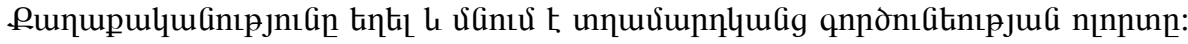

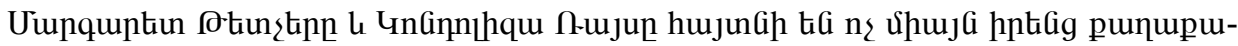

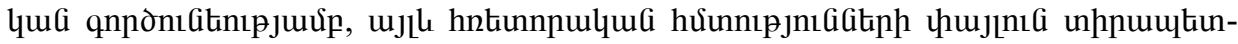

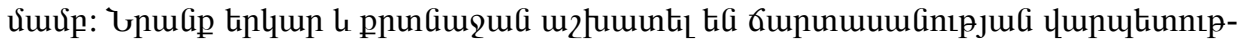

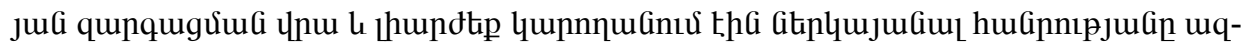

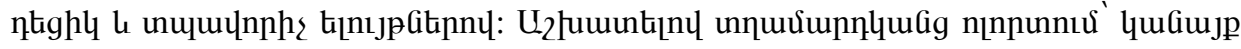

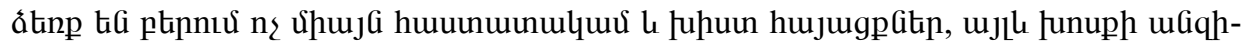

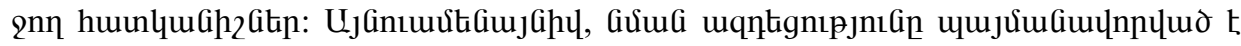

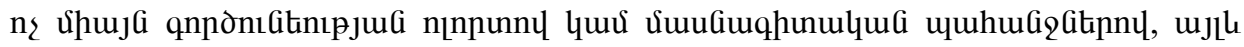

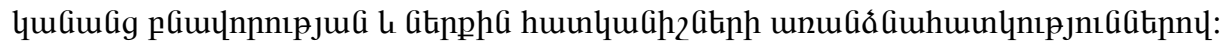

\section{Мужские черты речи \\ в дискурсе женщин-политиков}

Политика всегда была и остается сферой деятельности мужчин. Маргарет Тетчер и Кондолиза Райс известны не только политической деятельностью, но и мастерством красноречия. Оба политических деятеля в совершенстве владеют искусством политического выступления, искусством воздействия на аудиторию. Они серьезно и упорно работали над своим ораторским мастерством и в совершенстве владели искусством политического выступления, искусством воздействия на аудиторию. Работая в сфере деятельности мужчин, женщины приобретают не только строгие и неуступчивые взгляды, но и бескомпромиссную манеру речи. Подобное влияние не полностью обусловлено лишь сферой деятельности и профессиональными требованиями, но и внутренним стержнем политиков. 